\title{
Evaluation of Different Salts and Heavy Metal Concentrations on Bacterial Biofilm from Selected Surface and Borehole Water Samples
}

\author{
Dibua Nwamaka Anthonia ${ }^{1,}$, , Chukwura Edna Ifeoma ${ }^{2}$, Chude Charles Onuora ${ }^{1}$ \\ ${ }^{1}$ Department of Microbiology, Faculty of Natural Sciences, Chukwuemeka Odumegwu Ojukwu University, Uli, Nigeria \\ ${ }^{2}$ Department of Applied Microbiology and Brewing, Nnamdi Azikiwe University, Awka, Nigeria \\ Email address: \\ dibuatonia@gmail.com (D. N. Anthonia),ednaify@hotmail.com (C. E. Ifeoma), fortunelifas@yahoo.com (C. C. Onuora) \\ ${ }^{*}$ Corresponding author
}

To cite this article:

Dibua Nwamaka Anthonia, Chukwura Edna Ifeoma, Chude Charles Onuora. Evaluation of Different Salts and Heavy Metal Concentrations on Bacterial Biofilm from Selected Surface and Borehole Water Samples. Frontiers in Environmental Microbiology.

Vol. 6, No. 2, 2020, pp. 11-17. doi: 10.11648/j.fem.20200602.11

Received: February 28, 2020; Accepted: March 20, 2020; Published: April 23, 2020

\begin{abstract}
Biofilms in drinking water systems can serve as significant environmental reservoirs for pathogenic bacteria associated with gastro-enteric diseases. The evaluation of the effects of different salts and metal concentrations on bacterial biofilm from surface and borehole water samples was conducted. Water samples were collected, from 10 selected water sources of economic importance, aseptically using sterile containers. The physicochemical properties were investigated before the biofilm generation process. The collected water samples were allowed to stand in a secluded environment for four (4) weeks at $27^{\circ} \mathrm{C} \pm 2^{\circ} \mathrm{C}$ for biofilm generation. The isolates were characterized culturally, morphologically, biochemically and molecularly. The isolates were identified as Stenotrophomonas pavanii, Stenotrophomonas maltophilia, Chromobacterium violaceum, Bacillus cereus, Bacillus subtilis, Escherichia coli, and Pseudomonas aeruginosa. It was observed that the isolates exhibited growth at a wide range of temperature, salts, $\mathrm{pH}$, and metal salt concentrations. To determine the metal tolerance of the isolates, different concentrations $(0.05,0.1,0.5$, and $1.0 \%)$ of four metal salts; ferrous chloride $\left(\mathrm{FeCl}_{2}\right)$, zinc chloride $\left(\mathrm{ZnCl}_{2}\right)$, calcium chloride $\left(\mathrm{CaCl}_{2}\right)$, and magnesium oxide $(\mathrm{MgO})$ was used in nutrient broth. Their ability to grow in medium containing different salt $(\mathrm{NaCl})$ concentrations was also evaluated. Different concentrations of $\mathrm{NaCl}$ ranging from $2.0 \%$ to $10.0 \%$ were used in nutrient broth seeded with $0.1 \mathrm{ml}$ of the inocula and incubated at $37^{\circ} \mathrm{C}$ for 48 and 24 hours respectively. Growth was measured in terms of OD at $660 \mathrm{~nm}$ using spectrophotometer. Results showed a decline in the growth of the isolates with percentage increase in concentrations of all the metal salts. The result of the effect of $\mathrm{NaCl}$ salt on growth showed a decrease in growth with an increase in $\mathrm{NaCl}$ concentration from $2 \%$ to $10 \%$. For Stenotrophomonas pavanii, $\mathrm{FeCl}_{2}$ is negatively correlated with $\mathrm{pH} \mathrm{r}=-.998$ but there is positive correlation between $\mathrm{CaCl}_{2}$ and $\mathrm{NaCl}$ with $\mathrm{r}=889$.
\end{abstract}

Keywords: Biofilms, Isolates, Metals, Salts

\section{Introduction}

A biofilm is an assemblage of microbial cells in which cells adhere to each other on a surface. These adherent cells are enclosed in a self-produced matrix of extracellular polymeric substances (EPS) primarily composed of polysaccharide. An established biofilm structure comprises of microbial cells and EPS, has a defined architecture, and provides an optimal environment for the exchange of genetic materials between the cells. EPS may account for $50 \%$ to $90 \%$ of the total organic carbon of biofilms [7] and can be considered the primary matrix material of the biofilm. EPS may vary in chemical and physical properties, but it is primarily composed of polysaccharides. Some of these polysaccharides are neutral or polyanionic, as is the case of the EPS of Gram negative bacteria [6].

The presence of uronic acids (such as D-glucuronic, Dgalacturonic, and mannuronic acids) or ketal-linked pyruvates confers the anionic property [15]. This property is important because it allows association of divalent cations such as 
calcium and magnesium, which have been shown to cross-link with the polymer strands and provide greater binding force in a developed biofilm [7]. In the case of some gram-positive bacteria, such as the staphylococci, the chemical composition of EPS may be quite different and may be primarily cationic. Hussain et al., 1993 found that the slime of coagulase-negative bacteria consists of a teichoic acid mixed with small quantities of proteins [10].

EPS is also highly hydrated because it can incorporate large amounts of water into its structure by hydrogen bonding. EPS may be hydrophobic, although most types of EPS are both hydrophilic and hydrophobic [15] EPS may also vary in its solubility. Sutherland 2000 noted two important properties of EPS that may have a marked effect on the biofilm. First, the composition and structure of the polysaccharides determine their primary conformation. For example, many bacterial EPS possess backbone structures that contain 1,3 - or $1,4-\beta$-linked hexose residues and tend to be more rigid, less deformable, and in certain cases poorly soluble or insoluble. Other EPS molecules may be readily soluble in water. Second, the EPS of biofilms is not generally uniform but may vary spatially and temporally [15]. Leriche et al., 2000 used the binding specificity of lectins to simple sugars to evaluate bacterial biofilm development by different organisms. These researchers' results showed that different organisms produce differing amounts of EPS and that the amount of EPS increases with age of the biofilm [12]. EPS may associate with metal ions, divalent cations, other macromolecules (such as proteins, DNA, lipids, and even humic substances) [7]. EPS production is known to be affected by nutrient status of the growth medium; excess available carbon and limitation of nitrogen, potassium, or phosphate promote EPS synthesis. Slow bacterial growth will also enhance EPS production [15].

Microbes form biofilm in response to many factors, which may include cellular recognition of specific or non-specific attachment sites on surfaces, favorable environmental conditions, nutritional clues, or in some cases, by exposure of planktonic cells to sub-inhibitory concentration of antibiotics. When a cell switches to biofilm mode of growth, it undergoes a phenotypic shift in behavior in which large suites of genes are differentially regulated [11]. The attachment of microorganisms to surfaces is a very complex process, with many variables affecting the outcome. In general, attachment will occur most readily on surfaces that are rougher, more hydrophobic, and coated by surface "conditioning" films [5]. The characteristics of the aqueous medium, such as $\mathrm{pH}$, nutrient levels, ionic strength, and temperature, may play a role in the rate of microbial attachment to a substratum. Several studies have shown a seasonal effect on bacterial attachment and biofilm formation in different aqueous systems [4]. This effect may be due to water temperature or to other unmeasured, seasonally affected parameters. Fletcher and Loeb, found that an increase in the concentration of several cations (sodium, calcium, lanthanum, ferric iron) affected the attachment of Pseudomonas fluorescens to glass surfaces, presumably by reducing the repulsive forces between the negatively charged bacterial cells and the glass surfaces [8]. Cowan, et al., showed in a laboratory study that an increase in nutrient concentration correlated with an increase in the number of attached bacterial cells [3].

\section{Materials and Methods}

\subsection{Sample Collection}

The surface water samples were collected from Echem stream in Ogwuari village Nsugbe, Ori stream in Amanuke town, Ofifia stream Awka, Nnamdi Azikiwe University, Awka, Nkisi River in Onitsha and Nkisi spring water in Onitsha. The borehole water samples were collected from a borehole located at No. 3A Ogwugwu Lane, inland town, Onitsha; borehole located at Amagu village, Amanuke; a borehole at female hostel, Unizik Awka; borehole at No 5 Aduma Street, Obosi, and a borehole at Amaku Road, Awka, all in Anambra state, Nigeria.

\subsection{Generation of Biofilm}

Biofilm was generated from both the borehole water and surface water samples by allowing the water samples to stands for 4 weeks at room temperature. The waters were then discarded and the resulting slimy layer formed on the containers collected using swab sticks.

\subsection{Isolation of Biofilm Bacteria}

The biofilm generated from the water samples were inoculated on plates containing Reasoner's 2 agar (R2A medium contains $0.5 \mathrm{~g}$ of yeast extract powder, $0.5 \mathrm{~g}$ of protease peptone, $0.5 \mathrm{~g}$ of casimino acid, $0.5 \mathrm{~g}$ of glucose, $0.5 \mathrm{~g}$ of soluble starch, $0.3 \mathrm{~g}$ of sodium pyruvate, $0.3 \mathrm{~g}$ of $\mathrm{K}_{2} \mathrm{HPO}_{4}, 0.05 \mathrm{~g}$ of $\mathrm{MgSO}_{4}, 15 \mathrm{~g}$ of agar) and on nutrient agar plates for comparison. The inoculated plates were incubated at $37^{\circ} \mathrm{C}$ for $2-5$ days.

After incubation, colonies with visually distinguishable morphologies were randomly selected and isolated by directly streaking on nutrient agar plates and on R2A plates and incubated for 24-hours. The isolated colonies were subcultured on to nutrient agar plates to obtain pure cultures.

\subsection{Molecular Characterization of the Isolated Bacteria}

$\mathrm{N}$ - BLAST search of the 16S rRNA sequence of the isolated bacteria was reported by Bhat Biotech private Company India.

\subsection{Preparation of Inoculums}

Pure cultures of the isolates were transferred into $100 \mathrm{ml}$ Erlenmeyer flasks containing nutrient broth and incubated at $37^{\circ} \mathrm{C}$ for 24 -hour. The 24 hours old cultures were used as inocula in all the experiment.

\subsection{Effect of Temperature on the Growth of Isolates}

For determination of optimum temperature, $0.1 \mathrm{ml}$ inoculum each was provided into $10 \mathrm{ml}$ of nutrient broth medium and incubated overnight at different temperature ranging from 30 to $50^{\circ} \mathrm{C}$. Growth was measured in terms of 
optical density at $660 \mathrm{~nm}$ using spectrophotometer.

\subsection{Effect of pH on the Growth of Isolates}

$\mathrm{pH}$ is a limiting factor which governs bacterial growth. To determine $\mathrm{pH}$ optima, nutrient broth medium meant for the growth of the isolates was adjusted to different $\mathrm{pH}$ ranges 5.0 to 11.0 and seeded with $0.1 \mathrm{ml}$ of the inoculum. The culture was incubated overnight at $37^{\circ} \mathrm{C}$. Growth was measured as $\mathrm{OD}$ at $660 \mathrm{~nm}$ using spectrophotometer.

\subsection{Effect of Metals on Growth of Bacterial Isolates}

To determine the metal tolerance of the isolates, different concentration of four metal salts; Iron chloride $\left(\mathrm{FeCl}_{2}\right)$, Zinc chloride $\left(\mathrm{ZnCl}_{2}\right)$, Calcium chloride $\left(\mathrm{CaCl}_{2}\right)$, and Magnesium oxide $(\mathrm{MgO})$ were used in nutrient broth. Only $0.1 \mathrm{ml}$ of the inocula were seeded into tubes containing different concentrations of the metals and incubated at $37^{\circ} \mathrm{C}$ for 24hours. Growth was measured in terms of OD at $660 \mathrm{~nm}$ using spectrophotometer

\subsection{Effect of Salt ( $\mathrm{NaCl})$ Concentration on the Growth of Isolates}

To study the optimum salt concentration on bacterial growth, different concentrations of $\mathrm{NaCl}$ ranging from $2.0 \%$ to $10.0 \%$ were used in nutrient broth. Growth was measured in terms of OD at $660 \mathrm{~nm}$ using spectrophotometer

\section{Results}

\subsection{Effect of Temperature and $\mathrm{pH}$ on the Growth of Isolates}

Below is the result of the effects of temperature and $p H$ on the growth of the bacterial isolates. Growth was observed in all the isolates at the various temperature and $p H$ values. Gradual decrease in growth of the isolates was observed with a further increase in the temperature and $\mathrm{pH}$.

Table 1. Effect of Temperature on the growth of isolates.

\begin{tabular}{|c|c|c|c|c|c|}
\hline & \multicolumn{5}{|c|}{ Temperature $\left({ }^{\circ} \mathrm{C}\right)$} \\
\hline & 30 & 35 & 37 & 40 & $\mathbf{5 0}$ \\
\hline Stenotrophomonas pavanii & 1.230 & 1.490 & 1.650 & 1.278 & 0.143 \\
\hline Stenotrophomonas maltophilia & 1.120 & 1.356 & 1.520 & 1.194 & 0.160 \\
\hline Chromobacterium violaceum & 0.567 & 1.584 & 1.305 & 1.152 & 0.170 \\
\hline Bacillus cereus & 1.052 & 1.125 & 1.204 & 1.013 & 0.002 \\
\hline Bacillus subtilis & 1.345 & 1.560 & 1.120 & 1.020 & 0.064 \\
\hline E. coli & 0.430 & 1.500 & 1.245 & 0.230 & 0.120 \\
\hline
\end{tabular}

Table 2. Effect of different $p H$ values on growth of isolates.

\begin{tabular}{llllllll}
\hline & $\mathbf{p H ~ 5}$ & $\mathbf{p H ~ 6}$ & $\mathbf{p H ~ 7}$ & $\mathbf{p H ~ 8}$ & $\mathbf{p H ~ 9}$ & $\mathbf{p H ~ 1 0}$ \\
\hline S. pavanni & 0.044 & 0.162 & 0.327 & 0.559 & 0.236 & 0.246 \\
S. maltophilia & 0.346 & 0.432 & 0.500 & 0.657 & 0.387 & 0.331 \\
C. violaceum & 0.431 & 0.520 & 0.368 & 0.256 & 0.200 & 0.156 \\
Bacillus cereus & 0.121 & 0.185 & 0.240 & 0.311 & 0.307 & 0.137 \\
Bacillus subtillis & 0.320 & 0.200 & 0.156 & 0.735 & 0.580 & 0.125 \\
E. coli & 0.018 & 0.125 & 0.602 & 0.346 & 0.250 & 0.300 \\
P. aeruginosa & 0.050 & 0.305 & 0.120 & 0.305 & 0.470 & 0.650 \\
\hline
\end{tabular}

\subsection{Effect of Different Metal Concentrations on the Growth of Bacterial Isolates from Biofilms}

Effect of different metal concentrations on the growth of bacterial isolates showed that growth was observed at the different concentrations of the heavy metals as shown on the graphs below.

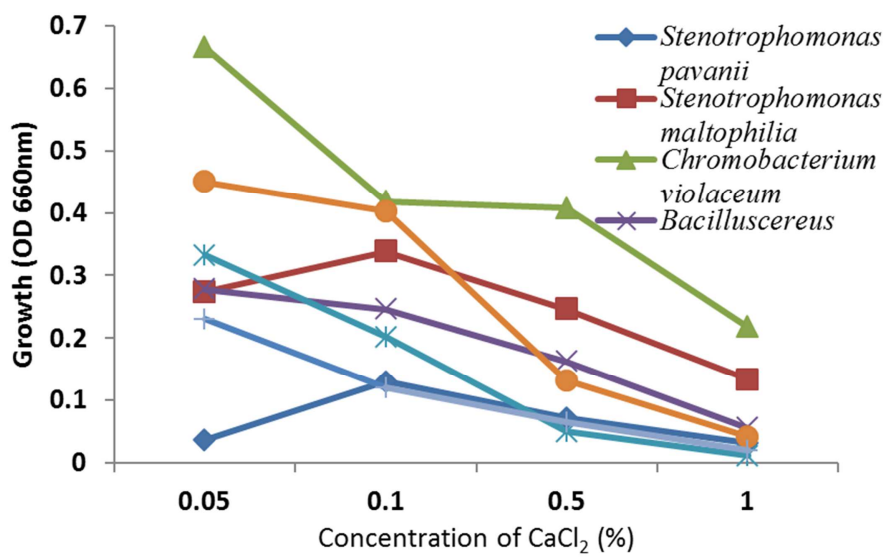

Figure 1. Effect of different concentrations of $\mathrm{CaCl}_{2}$ on growth of bacterial isolates. 
Effect of different concentrations of $\mathrm{CaCl}_{2}$ on the growth of the isolates showed a gradual decrease in growth of all the strains. However Stenotrophomonas maltophilia showed optimum growth at $0.1 \% \mathrm{CaCl}_{2}$ concentration, whereas
Bacillus subtilis, E. coli and $P$. aeruginosa grew best at $0.05 \% \mathrm{CaCl}_{2}$ concentration with the least growth observed in Bacillus subtilis at $1 \% \mathrm{CaCl}_{2}$ as shown in Figure 1.

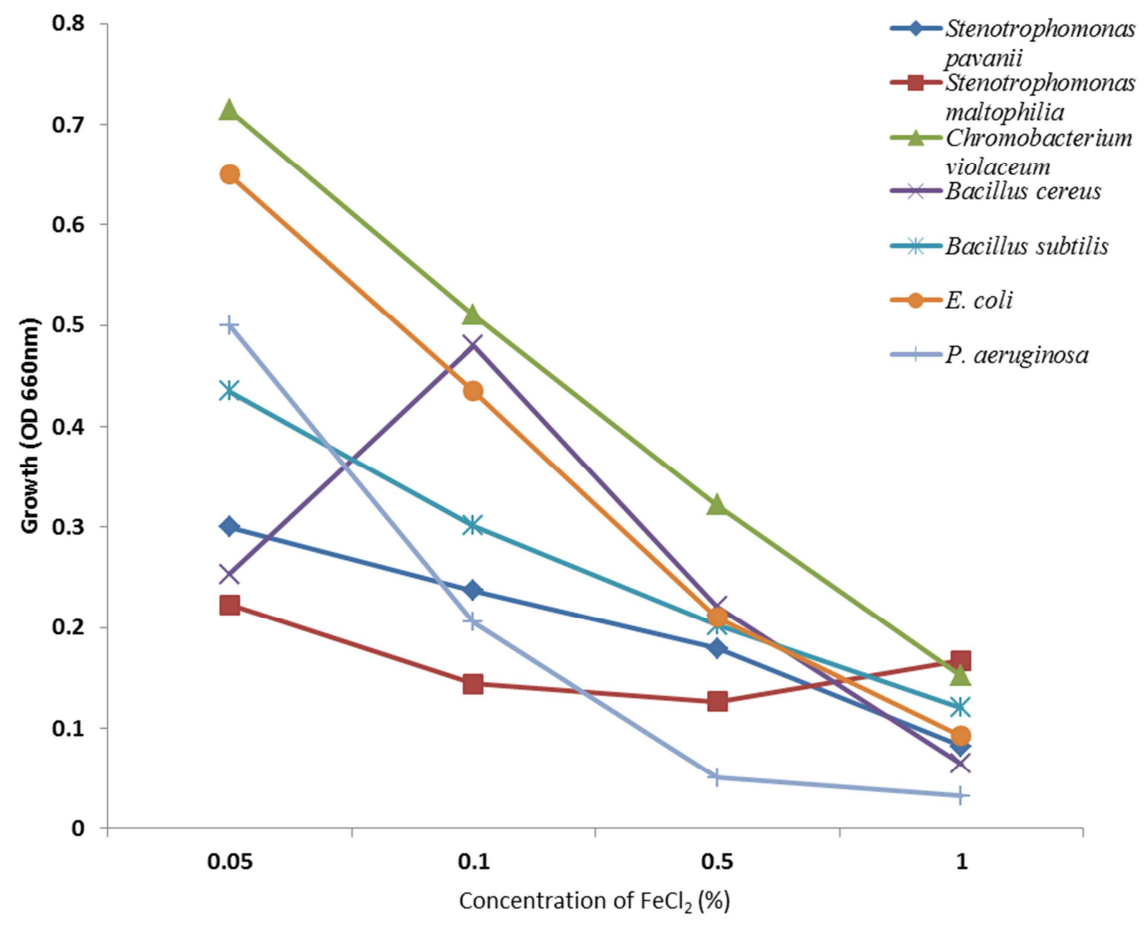

Figure 2. Effect of different concentration of $\mathrm{FeCl}_{2}$ on the growth of bacterial isolates.

A decline in the growth of the isolates with percentage increase in $\mathrm{FeCl}_{2}$ concentration is shown in Figure 2. Chromobacterium violaceum and $E$. coli showed best growth at $0.05 \% \mathrm{FeCl}_{2}$ concentration. Optimum growth was also observed in S. maltophilia, S. pavanii, and Bacillus subtilis at $0.05 \% \mathrm{FeCl}_{2}$ concentration while Bacillus cereus had its optimum growth at $0.1 \%$ concentration of $\mathrm{FeCl}_{2}$.

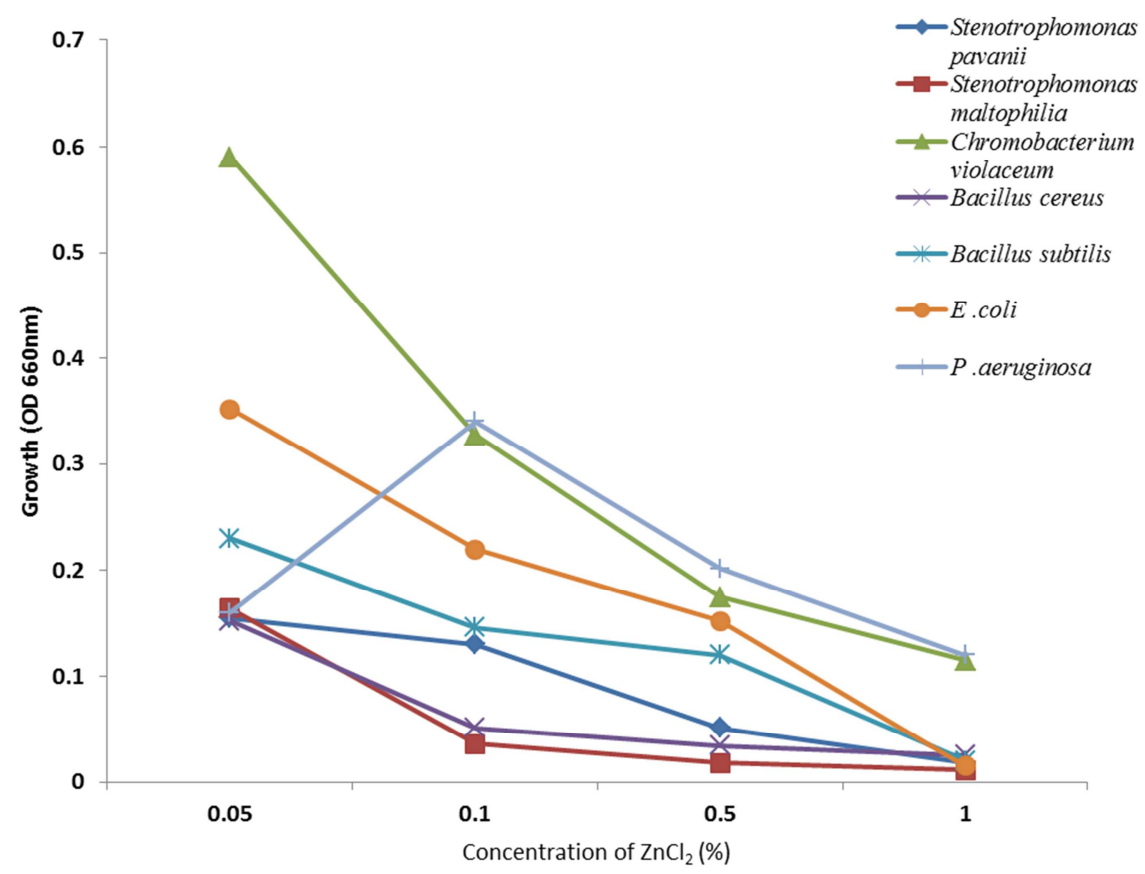

Figure 3. Effect of different concentrations of $\mathrm{ZnCl}_{2}$ on the growth of the isolates. 
The effect of different concentration of $\mathrm{ZnCl}_{2}$ showed a decrease in growth with an increase in concentration of $\mathrm{ZnCl}_{2}$ in all the organisms as shown in Figure 3. Chromobacterium violaceum gave the highest reading of 0.590 at $0.05 \%$ while $S$. maltophilia had the least growth with reading of 0.011 at $1 \% \mathrm{ZnCl}_{2}$ concentration. Optimum growth was at $0.05 \%$ concentration for $S$. maltophilia, $S$. pavanii, Bacillus cereus and Bacillus subtilis.

The effect of Magnesium Oxide on the growth of the isolates is shown in Figure 4. A decrease in growth was observed in all the isolates with percentage increase in $\mathrm{MgO}$ concentration. Stenotrophomonas pavanii showed optimum growth at concentration of $0.1 \%$, whereas optimum was at $0.5 \%$ concentration of Magnesium oxide for Stenotrophomonas maltophilia, Bacillus cereus and Chromobacterium violaceum. $0.05 \%$ concentration of Magnesium oxide was best for the growth of Bacillus subtilis, $P$. aeruginosa and E. coli.

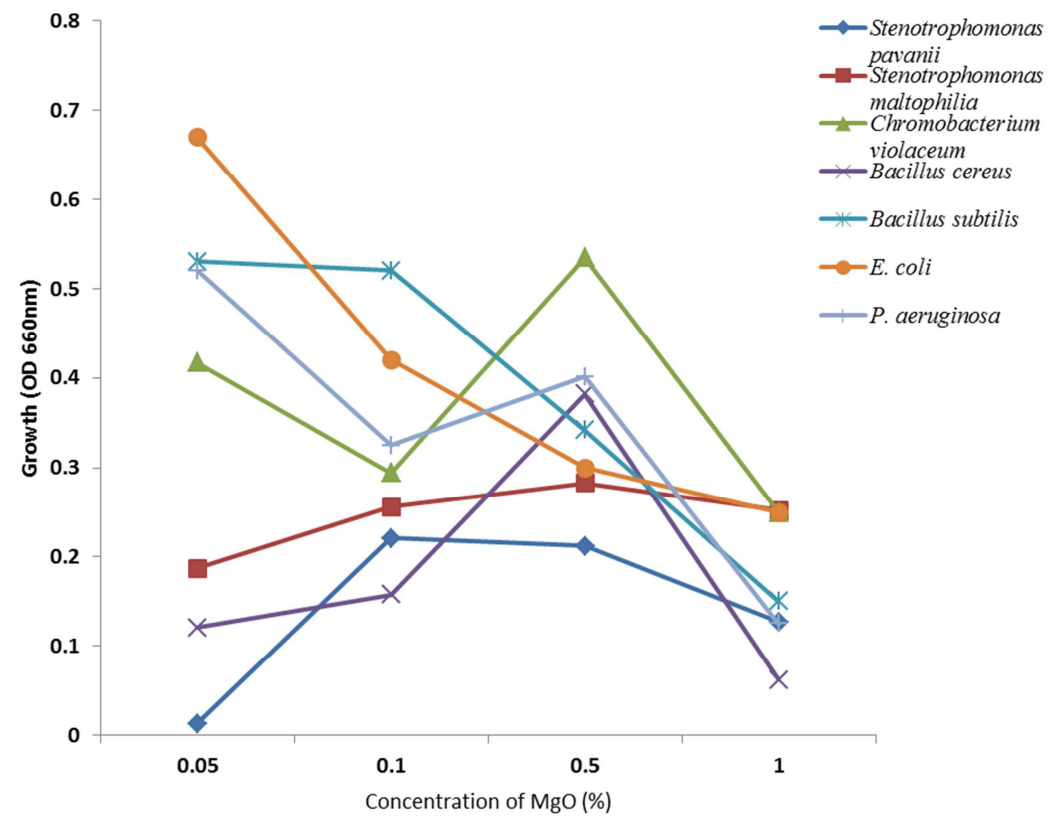

Figure 4. Effect of different concentrations of $\mathrm{MgO}$ on the growth of the isolates.

\subsection{Effect of Different Salt ( $\mathrm{NaCl}$ Concentrations on Growth of Isolates}

The effect of different salt concentrations on the growth of the bacterial isolates is shown in the figure below. Gradual decrease in growth was observed in all the isolates with a percentage increase in $\mathrm{NaCl}$ concentration.

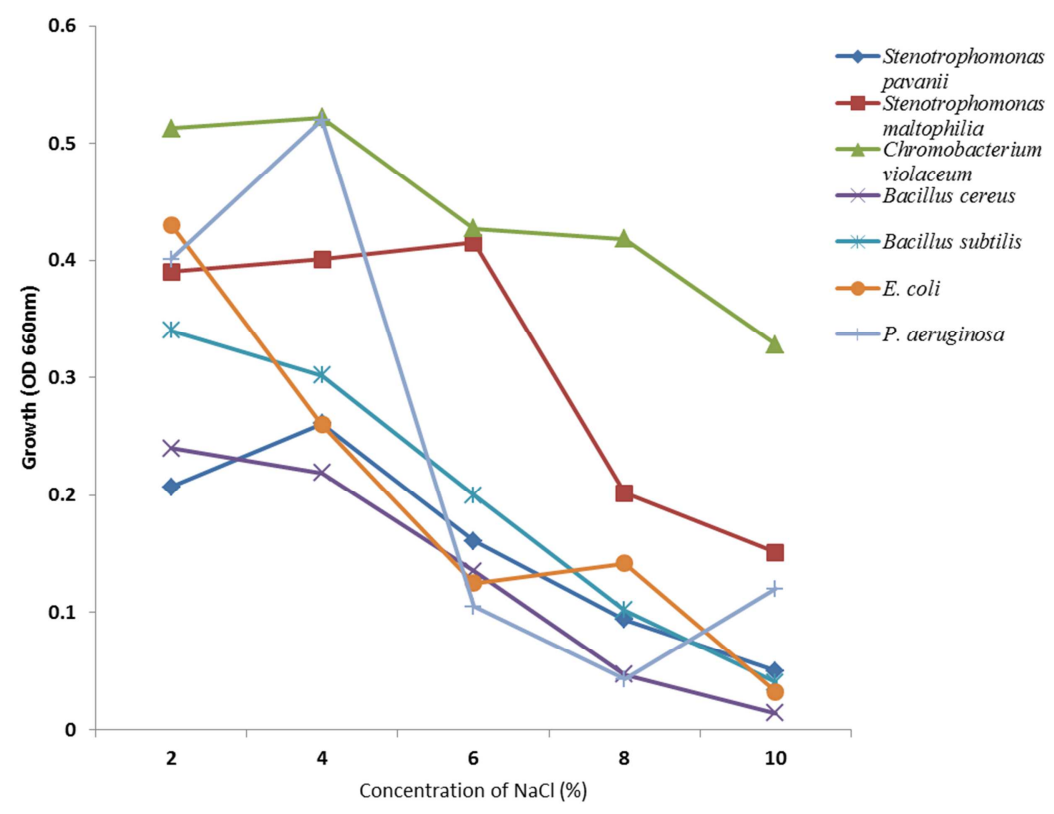

Figure 5. Effect of different Salt (NaCl) concentrations on growth of isolates. 
The effect of increase in concentration of Sodium chloride $(\mathrm{NaCl})$ on the growth of the isolates is shown in Figure 5. The optimum growth for Chromobacterium viloaceum Stenotrophomonas pavanii and $P$. aeruginosa was found at $4 \% \mathrm{NaCl}$ concentration and at $6 \% \mathrm{NaCl}$ concentration for Stenotrophomonas maltophilia. Two percent $\mathrm{NaCl}$ concentration was best for the growth of Bacillus cereus, Bacillus subtilis and E. coli.

\section{Discussion}

The work investigated the effect of different salts and heavy metal concentrations on bacterial biofilm from surface water and borehole water samples. The investigation highlights the presence of microorganisms that are able to come together and form biofilm.

Seven strains were selected based on their biochemical reaction and molecular characterization. The bacterial isolates were identified as Stenotrophomonas pavanii, Stenotrophonmonas maltophilia Chromobacterium violaceum, Bacillus cereus, Bacillus subtillis, Escherichia coli, and Pseudomonas aeruginosa. Since salt $(\mathrm{NaCl})$ concentration, temperature and $\mathrm{pH}$ have roles in enzymatic function as well as overall metabolic efficiency, these factors do have an effect on survivability and growth of microorganisms.

The effect of $\mathrm{pH}$ on the growth was evaluated and table 2 shows the $\mathrm{pH}$ profile of the strains indicating that the bacterial strains isolated were found to grow within the $\mathrm{pH}$ ranges of $5.0-11.0$. Optimum growth for Stenotrophomonas pavanii and stenotrophonmonas maltophilia was at $\mathrm{pH}$ of 8.0 and lesser growth were observed at $\mathrm{pH} 5.0$ and 11.0 for Stenotrophomonas pavanii and Stenotrophonmonas maltophilia respectively. Chromobacterium violaceum had its growth optimum at $\mathrm{pH} 6$ while Bacillus cereus and Bacillus subtilis grew best at $\mathrm{pH}$ 8.0. Similar result was recorded at $\mathrm{pH}$ ranges of $7.0-10.0$ for Bacillus cereus $[13 ; 1]$. Optimum growth was at $\mathrm{pH}$ of 7 and 10 for E. coli and P. aeruginosa respectively. Sivendra et al., reported similar result in $\mathrm{pH}$ value for growth of Chromobacterium violaceum at 5 to 9 and some at $\mathrm{pH}$ value of 4, 10 and 11[14]. Stenotrophomonas maltophilia showed the highest growth of OD 0.657 at $\mathrm{pH}$ 8.0 and least growth of $0.030 \mathrm{OD}$ at $\mathrm{pH} 11.0$.

In this study, the optimum temperature for growth of Stenotrophomonas pavanii (OD 1.650) Stenotrophonmonas maltophilia (OD 1.520) and Bacillus cereus (OD 1.204) was at $37^{\circ} \mathrm{C}$ as shown in table 1 , Confirming the work of Okanlawon [13] who reported that the optimum temperature for B. cereus is between $30^{\circ} \mathrm{C}$ and $37^{\circ} \mathrm{C}$ but some strains can grow at temperature as low as $4.5^{\circ} \mathrm{C}$ and up to $55^{\circ} \mathrm{C}$. Optimum temperature was at $35^{\circ} \mathrm{C}$ for Chromobacterium violacem, E. coli and $P$. aeruginosa. Further increase in temperature resulted in decrease in growth in all isolates.

The result figure 5 of the effect of $\mathrm{NaCl}$ salt on growth showed a decrease in growth with an increase in $\mathrm{NaCl}$ concentration from $2 \%$ to $10 \%$. Stenotrophomonas pavanii and $P$. aeruginosa had their optimum growth at $4 \%$ concentration and at $6 \% \mathrm{NaCl}$ concentration, Stenotrophonmonas maltophilia gave highest growth. Optimum growth was at $4 \%$ for Chromobacterium violaceum. This confirms the report that Chromobacterium violaceum grew at $4 \%$ and $5 \% \mathrm{w} / \mathrm{v}$ concentration of $\mathrm{NaCl}$ by Sivendra et al., [14]. Bacillus cereus, Bacillus subtilis and E. coli gave optimum growth at $2 \% \mathrm{w} / \mathrm{v}$ of $\mathrm{NaCl}$ concentration.

By affecting the growth, morphology and activities, heavy metal influence the microbial population and resulting in decreased biomass as well as diversity. Therefore microbes have developed mechanisms to tolerate the metal either by presence of heavy metals through efflux, complexation or reduction of metal ions or to use them as terminal election acceptors in anaerobic respiration [9]. Most mechanism reported involved the efflux of metal mechanisms has been found on both chromosomes and plasmids. Bacteria that are resistant to and grow on metals play an important role in the biogeochemical cycling of the metal ions [1]. Metal contamination is widespread. Heavy metals are defined as a group of metals whose atomic density is greater than $5 \mathrm{~g} / \mathrm{cm}^{2}$ in nature; there are about 50 heavy metals of special concern because of their toxicological effect to human beings and other living organisms. Many of them like $\mathrm{Zn}, \mathrm{Cu}, \mathrm{Co}, \mathrm{Mg}, \mathrm{Ni}, \mathrm{Mn}$ and $\mathrm{Fe}$ have nutritional characteristics known as essential trace element are necessary for living organisms [2] because at certain concentration levels, these elements participate in some enzyme activities. When in excess concentration, the toxic effects of these dual functional ions are revealed.

Result of the effect of different concentration of $\mathrm{CaCl}_{2}$ on growth of the isolates showed a gradual decrease in growth of all the strains with an increase in metal concentration. However, Stenotrophonmonas maltophilia showed highest growth of $0.338 \mathrm{OD}$ at $1 \%$ concentration of $\mathrm{CaCl}_{2}$, whereas Bacillus subtilis, E. coli and $P$. aeruginosa grew best at $0.05 \% \mathrm{CaCl}_{2}$ concentration as shown in Figure 1. Zinc chloride affected growth of the isolates in a similar manner. It was observed that $C$. violaceum had optimum growth $(0.590$ OD) at $0.05 \%$ of $\mathrm{ZnCl}_{2}$ concentration.

A decline in growth of the isolates was observed with a percentage increase in $\mathrm{FeCl}_{2}$ concentration figure 2 . Chromobacterium violaceum and $E$. coli showed best growth at $0.05 \%$ concentration. Increase in concentration of Magnesium oxide caused decrease in growth of the organisms. Stenotrophonmonas pavanii showed optimum growth at concentration of $0.1 \%$ whereas optimum for Stenotrophonmonas maltophilia was at $0.5 \%$ (0.283, OD) concentration of $\mathrm{MgO}$. Growth optimum was at $0.5 \%$ concentration of $\mathrm{MgO}$ for Bacillus cereus and Chromobacterium violaceum. $0.05 \%$ concentration of Magnesium oxide was best for the growth of Bacillus subtilis, $P$. aeruginosa and $E$. coli, with $E$. coli giving the highest growth (0.670 OD) as shown in figure 4 .

\section{Conclusion}

Microorganisms in water are able to attach to surfaces and 
form biofilms. All the borehole water and surface water sampled generated bacterial biofilms, which could be pathogenic to humans. The bacterial isolates include: Stenotrophomonas pavanii, Stenotrophomonas maltophilia, Chromobacterium violaceum, Bacillus cereus, Bacillus subtilis, Escherichia. coli, and Pseudomonas aeruginosa.

This work evaluated the effect of high concentrations of salts and heavy metals on the microbial population of the biofilm from water and has shown that despite the decline observed in growth of the isolates with an increase in the concentration of salt $(\mathrm{NaCl})$ as well as the heavy metal salts, the biofilms bacteria were able to thrive in adverse environmental conditions.

\section{References}

[1] Amalesh S., Paramita, B., Mahamuda, K., Chandrima, S. Pinaki, P., Asif, L. and Anurup Mandal (2012). An investigation on heavy metal tolerance and antibiotic resistance properties of bacterial strain Bacillus sp. Isolated from municipal waste. Journal of Microbiology and Biotechnology Research. 2 (1) 178-189.

[2] Brooun, A., Liu, S. and Lewis, K. (2000). A dose-response study of antibiotic resistance in Pseudomonas aeruginosa biofilms. Antimicrobial Agents and Chemotherapy 44: 640 646.

[3] Cowan, M. M., Warren, T. M. and Fletcher, M. (1991). Mixed species colonization of solid surfaces in laboratory biofilms. Biofouling 3 (1) 23-34.

[4] Donlan, R. M., Pipes, W. O., and Yohe, T. L. (1994). Biofilm formation on cast iron substrata in water distribution systems. Water Resources 28: 1497-503.

[5] Donlan, R. M. (2002). Biofilm control in industrial water systems: approaching an old problem in new ways. In: Evans LV, editor. Biofilms: recent advances in their study and control. Amsterdam: Harwood Academic Publishers. Pp. 33360 .
[6] Donlan, R. M. (2000). Role of biofilms in antimicrobial resistance. ASAIO Journal. 46: 47-52.

[7] Flemming, H. C., Wingender, J., Griegbe, and Mayer, C. (2000) Physicochemical properties of biofilms. In: Evans LV, editor. Biofilms: recent advances in their study and control. Amsterdam: Harwood Academic Publishers pp. 19-34.

[8] Fletcher M., and Loeb, G. I. (1979). Influence of substratum characteristics on the attachment a marine pseudomonad to solid surfaces. Applied and Environmental Microbiology. 37: $67-72$.

[9] Gadd, G. M. (1990). In: Microbial Mineral Research. Ehrlich, H. 1. and Brierley, L. C. (eds.) McGraw Hill, New York. pp 249-275.

[10] Hussain, M., Wilcox M. H. and White, P. J. (1993). The slime of coagulase-negative staphhylococci: biochemistry and relation to adherence. FEMS Microbiology Review 104: 191208.

[11] Karatan, E., and Watnick, P. (2009). "Signals, regulatory networks, and materials that build and break bacterial biofilms". Microbiology and Molecular Biology Reviews 73 (2): $310-47$.

[12] Leriche, V., Sibille, P. and Carpentier, B. (2000) Use of an enzyme-linked lectinsorbent assay to monitor the shift in polysaccharide composition in bacterial biofilms. Applied and Environmental Microbiology. 66: 1851-6.

[13] Okanlawon, B. M., Ogunbanwo, S. T. and Okunlola, A. O. (2010). Growth of Bacillus cereus isolated from some traditional condiments under different regimens. African Journal of Biotechnology. 8 (14): 2129-2135.

[14] Sivendra, R., Lo, S. and Lim, K. T. (1975). Identification of Chromobacterium violaceum: pigmented and non- pigmented strains. Journal of General Microbiology. 90: 21-31.

[15] Sutherland, I. W. (2001.) Biofilm exopolysaccharides: a strong and sticky framework. Microbiology. 147: 3-9. 